\title{
Kajian Dampak Pembuangan Air Limbah Industri PT. X Terhadap Sungai Cikijing di Provinsi Jawa Barat
}

\author{
Lina Apriyanti Sulistiowati dan Eka Wardhani \\ Jurusan Teknik Lingkungan, Fakultas Teknik Sipil dan Perencanaan, ITENAS, Bandung \\ Email: apriyanti06@gmail.com, ekw_wardhani@yahoo.com
}

\begin{abstract}
ABSTRAK
Sungai Cikijing termasuk ke dalam Sub DAS Citarik melintasi dua wilayah administrasi yaitu Kabupaten Sumedang dan Kabupaten Bandung. Sungai Cikijing menjadi sarana pembuangan air limbah dari aktivitas industri sehingga berpotensi menimbulkan pencemaran air sungai. Tujuan dilaksanakannya penelitian ini adalah menganalisis dampak pembuangan air limbah PT. X terhadap 3 aspek yaitu budidaya, kualitas air tanah dan tanah serta kesehatan masyarakat berdasarkan Peraturan Pemerintah Republik Indonesia Nomor 82 Tahun 2001. Kualitas air Sungai Cikijing pada Bulan Januari dan Agustus 2017 mengandung parameter yang tidak memenuhi bakumutu yaitu TSS, TDS, BOD, COD, Detergen MBAS, Belerang $\left(\mathrm{H}_{2} \mathrm{~S}\right)$, Minyak dan Lemak, Nitrit, Nitrat dan Fenol. Pencemaran yang terjadi di Sungai Cikijing tidak berpengaruh terhadap penurunan kesuburan tanah, karena air Sungai Cikijing tidak dijadikan sumber air irigasi untuk lahan pertanian di lokasi sampling. Analisis kualitas air bersih di lokasi studi diambil dari 2 lokasi dengan membandingkan bakumutu sesuai Permenkes RI No. 492 Tahun 2010. Parameter air sumur di Desa Linggar yang tidak memenuhi bakumutu yaitu kekeruhan, $\mathrm{Fe}, \mathrm{Mn}$, dan Zat Organik $\left(\mathrm{KmnO}_{4}\right)$. Sedangkan di Desa Jelegong parameter kekeruhan, pH, Fe, $\mathrm{Mn}$, dan Zat Organik $\left(\mathrm{KmnO}_{4}\right)$ tidak memenuhi baku mutu. Kualitas air sumur di kedua lokasi titik pemantauan tidak layak untuk di konsumsi harus dilakukan pengolahan terlebih dahulu sebelum dipergunakan untuk kebutuhan sehari-hari. Sungai Cikijing yang sudah tercemar dikhawatirkan dapat menurunkan kesehatan masyarakat. Data kesehatan masyarakat diperoleh dari Puskesmas Cisempur, Puskesmas Sawah Dadap, dan Puskesmas Rancaekek tahun 2015-2016 menunjukkan bahwa penyakit yang banyak diderita oleh masyarakat bukan sebagai akibat dari pencemaran air sungai Cikijing.
\end{abstract}

Kata Kunci: Sungai Cikijing, Industri, Pencemaran

\section{ABSTRACT}

Cikijing River is part of Citarik Sub watershed over two administrative areas of Sumedang and Bandung regencies. Cikijing river become a discharge media by industrial activity and thus potentially cause pollution of river water. The purpose of this research is to analyze the impact of waste disposal of PT. X against 3 aspects ie cultivation, groundwater and soil quality and public health based on Government Regulation of the Republic of Indonesia Number 82 Year 2001. Cikijing River water quality in January and August 2017 contains parameters that do not meet stream standard these are TSS, TDS, BOD, COD, detergents MBAs, sulfur $\left(\mathrm{H}_{2} \mathrm{~S}\right)$, oil and fat, nitrite, nitrate, and phenol. Pollution that occurred in the Cikijing River has no effect on the decline in soil fertility because the Cikijing River water is not used as a source of irrigation water for agricultural land in the sampling location. The analysis of clean water quality in the study sites was taken from 2 locations by comparing standard according to Permenkes RI. 492 of 2010. Water well parameters in Linggar village that do not meet the standard these are turbidity, $\mathrm{Fe}, \mathrm{Mn}$, and organic substances ( $\mathrm{KmnO}_{4}$ ). While in Jelegong Village, turbidity, $\mathrm{pH}, \mathrm{Fe}, \mathrm{Mn}$, and organic $\left(\mathrm{KmnO}_{4}\right)$ parameters did not meet the quality standard. The quality of the well water at both sites of the monitoring point is not feasible for consumption should be processed first before being used for daily needs. The polluted Cikijing River is feared to reduce public health. Public health data obtained from government public health facilities in Cisempur, Sawah Dadap, and Rancaekek in the year 2015-2016 show that the disease suffered by many people, not as a result of water pollution Cikijing river.

Keywords: Cikijing River, Industry, Pollution

Jurnal Rekayasa Hijau - 20 


\section{PENDAHULUAN}

Sub DAS Cikijing merupakan bagian dari Sub DAS Sungai Citarik akan bermuara di Sungai Citarum. Sub DAS Cikijing juga menerima percabangan aliran yaitu Sungai Cimande yang bergabung dengan Sungai Cikijing di Kecamatan Rancaekek. Sungai Cikijing melintasi dua wilayah administrasi yaitu Kabupaten Sumedang dan Kabupaten Bandung, sehingga wilayah sungai ini berada di bawah kewenangan Provinsi Jawa Barat. DAS Cikijing saat ini didominasi oleh berbagai aktivitas manusia yaitu kegiatan industri, domestik, pertanian, dan peternakan. Keadaan ini menyebabkan kualitas air Sungai Cikijing tercemar oleh limbah yang berasal dari keempat aktivitas manusia tersebut.

Berdasarkan Peraturan Pemerintan Republik Indonesia Nomor 82 Tahun 2001 tentang Pengelolaan Kualitas Air dan Pengendalian Pencemaran Air pada Pasal 36 disebutkan kajian dampak pembuangan air limbah merupakan kewajiban dari industri penghasil limbah. Hasil kajian sebagaimana dimaksud meliputi sekurang-kurangnya: (a) pengaruh terhadap pembudidayaan ikan, hewan, dan tanaman; (b) pengaruh terhadap kualitas tanah dan air tanah; dan (c) pengaruh terhadap kesehatan masyarakat.

Setiap penanggung jawab usaha dan atau kegiatan yang membuang air limbah ke air atau sumber air wajib mencegah dan menanggulangi terjadinya pencemaran air. Setiap penanggung jawab usaha dan atau kegiatan yang membuang air limbah ke air atau sumber air wajib mentaati persyaratan yang ditetapkan dalam izin. Dalam persyaratan izin pembuangan air limbah wajib dicantumkan: kewajiban untuk mengolah limbah; persyaratan mutu dan kuantitas air limbah yang boleh dibuang ke media lingkungan; persyaratan cara pembuangan air limbah; persyaratan untuk mengadakan sarana dan prosedur penanggulangan keadaan darurat; persyaratan untuk melakukan pemantauan mutu dan debit air limbah; persyaratan lain yang ditentukan oleh hasil pemeriksaan analisis mengenai dampak lingkungan yang erat kaitannya dengan pengendalian pencemaran air bagi usaha dan atau kegiatan yang wajib melaksanakan analisis mengenai dampak lingkungan; larangan pembuangan secara sekaligus dalam satu saat atau pelepasan dadakan; larangan untuk melakukan pengenceran air limbah dalam upaya penaatan batas kadar yang dipersyaratkan; dan kewajiban melakukan swapantau dan kewajiban untuk melaporkan hasil swapantau.

Tujuan dilaksanakannya penelitian ini adalah menganalisis dampak pembuangan air limbah PT. X terhadap 3 aspek yaitu 1) budidaya ikan, hewan dan tumbuhan, 2) kualitas air tanah dan tanah, 3)kesehatan masyarakat berdasarkan Peraturan Pemerintah Republik Indonesia Nomor 82 Tahun 2001 tentang Pengelolaan Kualitas Air dan Pengendalian Pencemaran Air.

\section{METODOLOGI}

Penelitian ini dilakukan di Sub Daerah Aliran Sungai (DAS) Cikijing dimana PT.X berada dengan parameter yang dikaji yaitu: (a) pengaruh terhadap pembudidayaan ikan, hewan, dan tanaman; (b) pengaruh terhadap kualitas tanah dan air tanah; dan (c) pengaruh terhadap kesehatan masyarakat. Pengaruh dampak pembuangan air limbah ke Sungai Cikijing terhadap pembudidayaan ikan, hewan, dan tanaman dilakukan di Sub DAS Cikijing yang berada di Sub DAS Cikijing terdiri dari 3 Kecamatan antara lain Kecamatan Jatinangor Kabupaten Sumedang (Desa Jatiroke, Desa Jatimukti, Desa Cisempur, dan Desa Cinta Mulya), Kecamatan Cimanggung Kabupeten Sumedang (Desa Mangunarga dan Desa Sawah Dadap), serta Kecamatan Rancaekek Kabupaten Bandung (Desa Linggar, Desa Jelegong, dan Desa Bojongloa).

Pengaruh dampak pembuangan air limbah ke Sungai Cikijing terhadap kualitas air tanah dan kesuburan tanah dilakukan di 3 titik yaitu: (1) Tanah Sawah Kampung Baturumpil Desa Cisempur Kecamatan Jatinangor Kabupaten Sumedang, (2) Tanah Sawah Kampung Rancakendal Desa Jelegong Kecamatan Rancaekek Kabupaten Bandung, dan (3) Tanah Sawah Kampung Babakan Jawa Desa Bojongloa Kecamatan Rancaekek Kabupaten Bandung. Analisis kualitas air bersih dari sumber air di lokasi studi diambil dari 2 lokasi yaitu sumur penduduk di Desa Linggar Rancaekek dan sumur penduduk di Desa Jelegong Kampung Ciherang, hasil analisis dibandingkan dengan baku mutu PERMENKES RI No. 492 Tahun 2010. Pengaruh dampak pembuangan air limbah ke Sungai Cikijing terhadap kesehatan masyarakat ditinjau dari jumlah penyakit terbanyak yang diderita oleh penduduk di 
3 puskesmas yang termasuk dalam wilayah Sub DAS Cikijing yaitu Puskesmas Cisempur, Sawah Dadap, dan Rancaekek.

\section{HASIL DAN PEMBAHASAN}

\subsection{Gambaran Umum Sub DAS Cikijing}

Sub DAS Cikijing terdiri dari 3 Kecamatan antara lain Kecamatan Jatinangor Kabupaten Sumedang (Desa Jatiroke, Desa Jatimukti, Desa Cisempur, dan Desa Cinta Mulya), Kecamatan Cimanggung Kabupeten Sumedang (Desa Mangunarga dan Desa Sawah Dadap), serta Kecamatan Rancaekek Kabupaten Bandung (Desa Linggar, Desa Jelegong, dan Desa Bojongloa). Berdasarkan data yang diperoleh dari Kecamatan Jatinangor dalam Angka 2016, Kecamatan Rancaekek dalam Angka 2016 dan Kecamatan Cimanggung dalam Angka 2016, rekapitulasi data penduduk yang masuk ke Sub DAS Cikijing diperkirakan sebanyak 90.378 jiwa [1,2]. Jumlah penduduk yang masuk wilayah Kabupaten Bandung lebih tinggi dibandingkan dengan yang berada di wilayah Kabupaten Sumedang. Tabel 1 menjabarkan jumlah penduduk yang berada di Sub DAS Cikijing.

Tabel 1. Jumlah Penduduk di Sub DAS Cikijing [1,2]

\begin{tabular}{cccc}
\hline \multirow{2}{*}{ Lokasi } & Kecamatan & Desa & $\begin{array}{c}\text { Total Penduduk } \\
\text { (Jiwa) }\end{array}$ \\
\hline Sungai & Jatinangor & Jatiroke & 5.832 \\
Cikijing & Kabupaten Sumedang & Jatimukti & 5.318 \\
\cline { 3 - 4 } Hulu & & Cisempur & 8.424 \\
\cline { 3 - 4 } & & Cinta Mulya & 8.139 \\
\cline { 3 - 4 } & Cimanggung & Mangunarga & 6.884 \\
\cline { 3 - 4 } & Kabupaten Sumedang & Sawah Dadap & 5.277 \\
\cline { 3 - 4 } Sungai & Rancaekek & Linggar & 12.351 \\
Cikijing & Kabupaten Bandung & Jelegong & 17.656 \\
\cline { 3 - 4 } Hilir & & Bojongloa & $\mathbf{9 0 . 3 7 9}$ \\
\hline \multicolumn{2}{c}{} \\
\cline { 3 - 4 }
\end{tabular}

Pengukuran kualitas dan kuantitas air dilaksanakan pada Bulan Agustus 2017 dengan titik sampling sebanyak 5 titik. Berdasarkan data hasil pengukuran debit air Sungai Cikijing di bagian Hulu yaitu sebesar $0,0577 \mathrm{~m}^{3} /$ detik, meningkat menjadi $0,1514 \mathrm{~m}^{3} /$ detik pada bagian tengah dan meningkat menjadi $0,2078 \mathrm{~m}^{3} /$ detik pada bagian hilir, demikian juga hasil pengukuran debit air Sungai Cimande bagian hilir sebesar $0,4275 \mathrm{~m}^{3} /$ detik. Parameter kualitas air yang diuji sebanyak 26 parameter yang terdiri dari 2 parameter Fisika, 22 parameter Kimia, dan 2 parameter mikrobiologi. Seluruh kualitas air yang dipantau dibandingkan dengan baku mutu berdasarkan Peraturan Pemerintah Nomor 82 Tahun 2001 tentang Pengelolaan Kualitas Air dan Pengendalian Pencemaran Air untuk kelas II prasaran/sarana rekreasi air, pembudidayaan ikan air tawar, peternakan, pertanaman, dan peruntukkan lain dengan syarat kualitas yang sama.

Berdasarkan hasil pengukuran kualitas air di 5 titik lokasi pengambilan sampling terdapat beberapa parameter yang melebihi baku mutu yang dipersyaratakan dalam Peraturan Pemerintah Nomor 82 Tahun 2001 tentang Pengelolaan Kualitas Air dan Pengendalian Pencemaran Air untuk kelas II antara lain parameter TSS, TDS, BOD, COD, detergen MBAS, belerang $\left(\mathrm{H}_{2} \mathrm{~S}\right)$, minyak dan lemak, nitrit, nitrat dan fenol. Berdasarkan perhitungan nilai Indeks Pencemaran Air (IP) hasil pemantauan Sungai Cikijing dan Sungai Cimande pada Bulan Agustus 2017 dari segmen hulu sampai dengan segmen hilir dengan membandingkan baku mutu Kelas II, menunjukkan bahwa semua titik lokasi yang dipantau memiliki status mutu Cemar Berat. Terjadinya pencemaran air sungai disebabkan oleh buangan limbah industri dan domestik yang masuk ke sungai sehingga menurunnya kualitas air sungai. Parameter yang dominan melampui Baku Mutu Kelas II, adalah Total Suspended Solid (TSS), Total Disolved Solid (TDS), BOD, COD, Total Phospat, Nitrat, Nitrit, Minyak dan Lemak, Sulfida sebagai $\mathrm{H}_{2} \mathrm{~S}$, Detergen MBAS, Clorin, Na serta SAR. 


\subsection{Pengaruh Terhadap Pembudidayaan Ikan, Hewan, dan Tanaman - Pertanian}

Dampak pembuangan air limbah terhadap budidaya ikan, hewan, dan tumbuhan yang akan dikaji meliputi pengaruh pencemaran yang terjadi di Sungai Cikijing terhadap sektor pertanian, peternakan, dan perikanan. Berdasarkan data yang diperoleh dari Kecamatan Jatinangor dalam Angka 2016, Kecamatan Rancaekek dalam Angka 2016 dan Kecamatan Cimanggung dalam Angka 2016. Luas sawah yang ada di Sub DAS Cikijing yaitu 675,5 Ha, palawija seluas 121,8 Ha dan perkebunan seluas 4,0 Ha. luas sawah terbesar berada di Desa Jelegong Kecamatan Rancaekek diikuti oleh Desa Bojongloa di kecamatan yang sama. Untuk luas palawija terbesar terdapat di Desa Jatimukti Kecamatan Jatinangor demikian juga dengan luas perkebunan lainnya. Berikut ini rekapitulasi data sektor pertanian yang ada di Sungai Cikijing Hulu dan Hilir. Untuk lebih lebih jelasnya dapat dilihat pada Tabel 2.

Tabel 2. Data Pertanian di Wilayah Sungai Cikijing Bagian Hulu dan Hilir [1,2]

\begin{tabular}{|c|c|c|c|c|c|}
\hline \multirow{2}{*}{ Lokasi } & \multirow{2}{*}{ Kecamatan } & \multirow{2}{*}{ Desa } & \multicolumn{3}{|c|}{ Luas Lahan Pertanian (Ha) } \\
\hline & & & Sawah & Palawija & Perkebunan Lain \\
\hline \multirow{5}{*}{$\begin{array}{c}\text { Sungai } \\
\text { Cikijing Hulu }\end{array}$} & \multirow{3}{*}{$\begin{array}{c}\text { Jatinangor } \\
\text { Kabupaten Sumedang }\end{array}$} & Jatimukti & 68,0 & 83,0 & 2,0 \\
\hline & & Cisempur & 13,0 & 31,0 & 0,0 \\
\hline & & Cinta Mulya & 8,0 & 0,0 & 2,0 \\
\hline & \multirow{2}{*}{$\begin{array}{c}\text { Cimanggung } \\
\text { Kabupaten Sumedang }\end{array}$} & Mangunarga & 0,0 & 0,0 & 0,0 \\
\hline & & Sawah Dadap & 11,0 & 0,0 & 0,0 \\
\hline \multirow{3}{*}{$\begin{array}{c}\text { Sungai Cikijing } \\
\text { Hilir }\end{array}$} & \multirow{3}{*}{$\begin{array}{c}\text { Rancaekek } \\
\text { Kabupaten Bandung }\end{array}$} & Linggar & 170,8 & 2,8 & 0,0 \\
\hline & & Jelegong & 227,2 & 0,8 & 0,0 \\
\hline & & Bojongloa & 177,5 & 4,2 & 0,0 \\
\hline & Jumlah & & 675,5 & 121,8 & 4,0 \\
\hline
\end{tabular}

Wilayah dengan luas sawah terbesar terdapat di Kecamatan Rancaekek terutama di Desa Jelegong, Bojongloa, dan Linggar, wilayah yang memiliki luas lahan palawija terbesar yaitu Desa Jatimukti Kecamatan Jatinangor, diikuti oleh Desa Cisempur pada kecamatan yang sama. Luas lahan perkebunan hanya terdapat di Desa Jatimukti, dan Cinta Mulya Kecamatan Jatinangor. PT. X terdapat di Desa Cinta Mulya dan Desa Cisempur Kecamatan Jatinangor dan Desa Mangunarga Kecamatan Cimanggung, yang memiliki luas lahan pertanian yang paling rendah dibandingkan dengan desa lainnya yang terdapat di Sub DAS Cikijing. Kehadiran PT. X tidak menimbulkan dampak negatif terhadap budidaya lahan pertanian di wilayah ini. Pencemaran yang terjadi di Sungai Cikijing tidak mempengaruhi budidaya lahan pertanian di wilayah ini.

\section{- Peternakan}

Berdasarkan data yang diperoleh dari Kecamatan Jatinangor dalam Angka 2016 , Kecamatan Rancaekek dalam Angka 2015, dan Cimanggung dalam Angka 2016 rekapitulasi data sektor peternakan yang ada di sekitar lokasi kegiatan. Berdasarkan data yang di peroleh dari Kecamatan Dalam Angka 2016, jumlah hewan ternak yang terbesar ada di ternak unggas seperti ayam dengan jumlah sebesar 4.520 ekor. Untuk ternak sedang jumlah yang paling besar adalah domba dengan jumlah 175 ekor, sedangkan untuk ternak besar jumlah yang paling besar adalah kerbau dengan jumlah sebesar 57 ekor Data perternakan dapat dilihat pada Tabel 3.

Tabel 3. Data Peternakan di Sekitar Lokasi Kegiatan [1,2]

\begin{tabular}{|c|c|c|c|c|c|c|c|c|c|}
\hline \multirow{2}{*}{ Lokasi } & \multirow{2}{*}{ Kecamatan } & \multirow{2}{*}{ Desa } & \multicolumn{7}{|c|}{ Jumlah Ternak (ekor) } \\
\hline & & & Kerbau & Sapi & Kuda & Domba & Kambing & Ayam & Bebek \\
\hline \multirow{5}{*}{$\begin{array}{c}\text { Sungai } \\
\text { Cikijing } \\
\text { Hulu }\end{array}$} & \multirow{3}{*}{$\begin{array}{l}\text { Jatinangor } \\
\text { Kabupaten } \\
\text { Sumedang }\end{array}$} & Jatimukti & 23,0 & 0,0 & 0,0 & 36,0 & 0,0 & 387,0 & 735,0 \\
\hline & & Cisempur & 2,0 & 0,0 & 0,0 & 22,0 & 0,0 & 207,0 & 30,0 \\
\hline & & Cinta Mulya & 4,0 & 0,0 & 0,0 & 20,0 & 0,0 & 265,0 & 0,0 \\
\hline & \multirow{2}{*}{$\begin{array}{l}\text { Cimanggung } \\
\text { Kabupaten } \\
\text { Sumedang }\end{array}$} & Mangunarga & 0,0 & 0,0 & 0,0 & 0,0 & 0,0 & 0,0 & 0,0 \\
\hline & & Sawah Dadap & 0,0 & 0,0 & 0,0 & 0,0 & 0,0 & 0,0 & 0,0 \\
\hline
\end{tabular}


Lina Apriyanti Sulistiowati dan Eka Wardhani

\begin{tabular}{cccrrrrrrr}
\hline \multirow{2}{*}{ Lokasi } & \multirow{2}{*}{ Kecamatan } & \multirow{2}{*}{ Desa } & \multicolumn{8}{c}{ Jumlah Ternak (ekor) } \\
\cline { 3 - 9 } & & & Kerbau & Sapi & Kuda & Domba & Kambing & Ayam & Bebek \\
\hline Sungai & Rancaekek & Linggar & 0,0 & 4,0 & 5,0 & 36,0 & 0,0 & 156,0 & 565,0 \\
\cline { 3 - 10 } Cikijing & Kabupaten & Jelegong & 10,0 & 0,0 & 0,0 & 24,0 & 0,0 & $1.003,0$ & 945,0 \\
\cline { 3 - 10 } Hilir & Bandung & Bojongloa & 18,0 & 3,0 & 4,0 & 37,0 & 12,0 & $2.508,0$ & 739,0 \\
\hline & & Jumlah & $\mathbf{5 7 , 0}$ & $\mathbf{7 , 0}$ & $\mathbf{9 , 0}$ & $\mathbf{1 7 5 , 0}$ & $\mathbf{1 2 , 0}$ & $\mathbf{4 . 5 2 0 , 0}$ & $\mathbf{3 . 0 1 4 , 0}$ \\
\hline
\end{tabular}

Peternakan ayam terbanyak berada di Desa Bojongloa Kecamatan Rancaekek demikian juga untuk ternak domba. PT. X terdapat di Desa Cinta Mulya dan Desa Cisempur Kecamatan Jatinangor dan Desa Mangunarga Kecamatan Cimanggung, berdasarkan Tabel 3 di sekitar lokasi PT.X hanya terdapat peternakan ayam, bebek, kerbau, dan domba dimana berdasarkan hasil wawancara dengan masyarakat pemilik ternak kehadiran PT. X tidak menimbulkan dampak negatif terhadap perkembangbiakan peternakan di wilayah ini. Berdasarkan data yang diperoleh dari Kecamatan Jatinangor dalam Angka 2016, dan Kecamatan Cimanggung dalam Angka 2016, di lokasi yang masuk ke Sub DAS Cikijing tidak ada data terkait sektor perikanan sehingga tidak dilakukan pembahasan.

\section{- Biota perairan}

Biota perairan merupakan organisma yang hidup diperairan, biota perairan yang diamati dalam laporan ini adalah mengenai ikan, plankton dan benthos. Kondisi biota perairan akan dipengaruhi oleh adanya kegiatan di darat. Pengaruh tersebut akan dilihat dari keanekaragamannya. Apabila keanekaragaman plankton dan benthos baik maka pertumbuhan ikan (nekton) akan baik. Berdasarkan hasil wawancara jenis ikan yang ditemukan di Sungai Citaraju (bagian dari Sungai Cimande) adalah ikan lele (Clarias batrahus), ikan betik (Anabas testudineus), ikan sepat (Trichogaster trichopterus) dan belut (Monopterus albus). Sedangkan di perairan Sungai Cikijing tidak ditemukan jenis ikan karena kualitas airnya tidak memungkinkan jenis ikan dapat hidup kecuali ikan sapu. Plankton merupakan organisma yang hidup terapung dan terbawa arus air. Plankton terdiri dari phytoplankton sebagai produsen primer dan zooplankton sebagai konsumen primer. Kehidupan plankton tergantung kepada kualitas air permukaan atau nutrien yang terlarut di dalam perairan tersebut. Oleh karena itu kegiatan yang ada di darat dan terbawa oleh arus hujan atau yang dibuang ke badan perairan akan mempengaruhi kehidupan plankton terutama keanekaragamannya.

Pengamatan dilakukan di dua sungai yaitu Sungai Cikijing dan Sungai Cimande. Secara keseluruhan ditemukan 5 jenis phytoplankton yaitu Closterium setaceum, Oscillatoria sp, Phormidium sp, Spirogyra sp, Spirulina laxissima dan 2 jenis zooplankton yaitu Cyclops sp, Pangrolaimus sp. Limbah domestik dari penduduk sekitar. PT X dan limbah industri lain keanekaragaman phytoplankton 0,32 dan didominasi oleh Phormidium sp sedangkan zooplanktonnya kosong. Keanekaragaman planktonnya 0,32 hal tersebut apabila dibandingkan dengan kriteria dari Odum [7] termasuk tercemar atau telah mengalami gangguan. Sungai Cikijing dari Hulu sampai Hilir yaitu stasiun 2, 3, 5 mempunyai keanekaragaman phytoplankton antara 0,28-0,45, sedangkan untuk stasiun 3 merupakan Sungai Cikijing irigasi. Keanekaragaman phytoplankton Sungai Cikijing Hulu dan Hilir yaitu stasiun, 3, dan 5 keanekaragamannya 0,34 dan 0,28 hal tersebut tidak jauh berbeda dan apabila dibandingkan dengan kriteria dari Odum [7] termasuk tercemar atau telah mengalami gangguan. Stasiun 3 merupakan Sungai Cikijing irigasi keanekaragaman phytoplanktonnya 0,45 hal tersebut apabila dibandingkan dengan kriteria dari Odum [7] termasuk tercemar atau telah mengalami gangguan karena Sungai Cikijing irigasi kondisi perairanya keruh yang akan mengganggu proses fotosintesa. Keanekaragaman zooplankton Sungai Cikijing hulu dan hilir yaitu kosong atau 0 begitu pula untuk Sungai Cikijing irigasi keanekaragaman zooplanktonnya kosong (nol). Sedangkan Untuk keanekaragaman plankton Sungai Cikijing Hulu dan Hilir yaitu stasiun, 3 dan 5 masing masing 0,38 dan 0,45 hal tersebut mengalami kenaikan dikarenakan turun hujan tetapi stasiun 5 terdapat satu jenis zooplankton yaitu Cyclops sp. Keanekaragaman plankton Sungai Cikijing irigasi yaitu stasiun 3 sebesar 0,56. Apabila dilihat secara keseluruhan keanekaragaman plankton Sungai Cikijing menurut Odum [7] termasuk tercemar atau telah mengalami gangguan. Sungai Cimande Hilir yaitu stasiun 4 nilai keanekaragaman phytoplankton 0,44 keanekaragaman zooplanktonnya 0 dan keanekaragaman 
planktonnya 0,43 apabila dibandingkan dengan kriteria dari Odum [7] maka Sungai Cimande hilir sudah termasuk tercemar atau telah mengalami gangguan. Jadi kedua sungai yaitu Sungai Cikijing Hilir dan Sungai Cikijing sekitar pabrik PT. X menurut Odum [7] termasuk tercemar atau telah mengalami gangguan.

\section{- Benthos}

Benthos merupakan organisma yang hidup tetap didasar perairan sehingga lebih cocok digunakan sebagai indikator pencemaran. Komposisi benthos di Sungai Cikijing. Indeks keanekaragaman benthos berdasarkan metode Shannon di lokasi saluran limbah domestik dari penduduk sekitar PT. X dan limbah industri lain yaitu stasiun 1 adalah 0,41 dengan jenis benthos yang dominan yaitu Lumbricus sp. Apabila indek keanekaragaman tersebut dibandingkan dengan kriteria Lee at al (1978) maka perairan ini sudah termasuk tercemar berat.

Indeks keanekaragaman benthos di lokasi Hulu Sungai Cikijing yaitu di jembatan dekat PT. X (stasiun 3) dan Hilir Sungai Cikijing yaitu stasiun 5 masing masing adalah 0 dan 0,41 dengan jenis benthos yang dominan Lumbricus sp. dan Tendipes sp. Apabila indeks keanekaragaman benthos Sungai Cikijing di hulu dan hilir dibandingkan dengan kriteria Lee et al [4] maka sudah termasuk tercemar berat. Indeks keanekaragaman benthos di lokasi Sungai Cikijing irigasi yaitu stasiun 2 adalah 0,64 dengan jenis benthos yang dominan Lumbricus sp. Apabila indeks keanekaragaman benthos Sungai Cikijing irigasi dibandingkan dengan kriteria Lee et al [6] maka sudah termasuk tercemar berat. Sedangkan untuk indeks keanekaragaman benthos di lokasi Sungai Cimande yaitu stasiun 4 adalah 0,56 dengan jenis benthos yang dominan yaitu Lumbricus sp. Apabila indeks keanekaragaman benthos Sungai Cimande dibandingkan dengan kriteria Lee et al [6] maka perairan ini sudah termasuk tercemar berat.

\subsection{Pengaruh Terhadap Kualitas Tanah dan Air Tanah Kesuburan Tanah}

Untuk melihat pengaruh pencemaran air Sungai Cikijing terhadap kualitas tanah yaitu dengan menganalisis kualitas tanah di tiga lokasi yang berada di Kampung Baturumpil Desa Cisempur Kecamatan Jatinangor Kabupaten Sumedang, Kampung Rancakendal Desa Jelegong Kecamatan Rancaekek Kabupaten Bandung, dan Kampung Babakan Jawa Desa Bojongloa Kecamatan Rancaekek Kabupaten Bandung. Berdasarkan hasil analisis tanah sawah pada lokasi penelitian yaitu:

Tabel 4. Hasil Analisis Kesuburan Tanah

\begin{tabular}{|c|c|c|c|c|c|}
\hline \multirow{2}{*}{\multicolumn{2}{|c|}{ Parameter }} & \multirow{2}{*}{ Satuan } & \multicolumn{3}{|c|}{ Lokasi Sampling } \\
\hline & & & 1 & 2 & 3 \\
\hline \multicolumn{2}{|c|}{ DHL } & mmhos/cm & 0,853 & 2,57 & 2,99 \\
\hline \multirow{3}{*}{ Tekstur } & Pasir & $\%$ & - & - & - \\
\hline & Debu & & - & - & - \\
\hline & Liat & & - & - & - \\
\hline \multirow[t]{2}{*}{$\mathrm{PH}$} & $\mathrm{H}_{2} \mathrm{O}$ & - & 6,42 & 6,35 & 6,28 \\
\hline & KCI & & 5,48 & 5,32 & 5,33 \\
\hline \multirow{3}{*}{$\begin{array}{c}\text { Bahan } \\
\text { Organik }\end{array}$} & $\mathrm{C}$ & $\%$ & 9,93 & 7,92 & 10,31 \\
\hline & $\mathrm{N}$ & & 0,34 & 0,28 & 0,45 \\
\hline & $\mathrm{C} / \mathrm{N}$ & - & 29 & 28 & 23 \\
\hline \multirow[t]{2}{*}{ Total } & $\mathrm{P}_{2} \mathrm{O}_{5}$ & $\mathrm{mg} / 100 \mathrm{~g}$ & 30,01 & 25,13 & 31,97 \\
\hline & $\mathrm{K}_{2} \mathrm{O}$ & & 22,15 & 25,40 & 29,79 \\
\hline E.BII & O-PO & $\mathrm{mg} / \mathrm{kg}$ & 142,6 & 116,7 & 107,5 \\
\hline \multirow{6}{*}{$\begin{array}{c}\text { Exch. } \\
\mathrm{NH}_{4} \mathrm{OAc} \mathrm{pH} \\
7,00\end{array}$} & $\mathrm{~K}$ & $\mathrm{me} / 100 \mathrm{~g}$ & 0,12 & 0,11 & 0,13 \\
\hline & $\mathrm{Na}$ & & 0,41 & 0,41 & 0,40 \\
\hline & $\mathrm{Ca}$ & & 3,28 & 1,49 & 2,69 \\
\hline & $\mathrm{Mg}$ & & 1,16 & 0,58 & 0,29 \\
\hline & TB & & 4,97 & 2,59 & 3,51 \\
\hline & KTK & & 15,99 & 20,89 & 22,02 \\
\hline Ekstrak & AI & & $\mathrm{tt}$ & $\mathrm{Tt}$ & $\mathrm{tt}$ \\
\hline
\end{tabular}

Jurnal Rekayasa Hijau - 25 


\begin{tabular}{|c|c|c|c|c|c|}
\hline \multirow{2}{*}{\multicolumn{2}{|c|}{ Parameter }} & \multirow{3}{*}{ Satuan } & \multicolumn{3}{|c|}{ Lokasi Sampling } \\
\hline & & & \multirow{2}{*}{$\begin{array}{c}\mathbf{1} \\
0,11 \\
\end{array}$} & \multirow{2}{*}{$\begin{array}{c}\mathbf{2} \\
0,09\end{array}$} & \multirow{2}{*}{$\begin{array}{c}\mathbf{3} \\
0,09 \\
\end{array}$} \\
\hline KCI.N & $\mathrm{H}$ & & & & \\
\hline & Basa & $\%$ & 31,08 & 12,35 & 15,94 \\
\hline & Efektif & & 99,32 & 96,63 & 97,50 \\
\hline & $\mathrm{AI}$ & & - & - & - \\
\hline \multicolumn{2}{|c|}{ SAR } & - & 0,28 & 0,39 & 0,33 \\
\hline
\end{tabular}

Keterangan:

1. Tanah Sawah Kampung Baturumpil Desa Cisempur Kec. Jatinangor Kab. Sumedang

2. Tanah Sawah Kampung Rancakendal Desa Jelegong Kec. Rancaekek Kab. Bandung

3. Tanah Sawah Kampung Babakan Jawa Desa Bojongloa Kec. Rancaekek Kab Bandung

Kriteria penilaian sifat kimia tanah disajikan pada Tabel 4, tabel tersebut dipergunakan untuk menilai sifat kimia tanah seperti disajikan pada Tabel 5.

Tabel 5. Kriteria Penilaian Sifat Kimia Tanah

\begin{tabular}{|c|c|c|c|c|c|}
\hline \multirow{2}{*}{\multicolumn{2}{|c|}{ Parameter }} & \multirow{2}{*}{ Satuan } & \multicolumn{3}{|c|}{ Lokasi Sampling } \\
\hline & & & 1 & 2 & 3 \\
\hline $\mathrm{C}$ & & \multirow{2}{*}{$\%$} & ST & ST & ST \\
\hline $\mathrm{N}$ & & & $\mathrm{S}$ & $\mathrm{S}$ & $\mathrm{S}$ \\
\hline $\mathrm{C} / \mathrm{N}$ & & - & ST & ST & ST \\
\hline $\mathrm{P}_{2} \mathrm{O}_{5}$ & \multirow{2}{*}{ HCI $25 \%$} & \multirow{2}{*}{$\mathrm{mg} / 100 \mathrm{~g}$} & $\mathrm{~S}$ & $\mathrm{~S}$ & $\mathrm{~S}$ \\
\hline $\mathrm{K}_{2} \mathrm{O}$ & & & ST & ST & ST \\
\hline $\mathrm{P}_{2} \mathrm{O}_{5}$ & BII & $\mathrm{mg} / \mathrm{kg}$ & ST & ST & ST \\
\hline KTK & \multirow{5}{*}{$\begin{array}{l}\mathrm{NH}_{4} \mathrm{OAc} \\
\text { pH. } 7.00\end{array}$} & \multirow{5}{*}{$\mathrm{me} / 100 \mathrm{~g}$} & $\mathrm{R}$ & $\mathrm{R}$ & $\mathrm{R}$ \\
\hline $\mathrm{K}$ & & & $\mathrm{R}$ & $\mathrm{R}$ & $\mathrm{R}$ \\
\hline $\mathrm{Na}$ & & & $\mathrm{S}$ & $S$ & $\mathrm{~S}$ \\
\hline $\mathrm{Ca}$ & & & $\mathrm{R}$ & SR & $\mathrm{R}$ \\
\hline $\mathrm{Mg}$ & & & SR & SR & SR \\
\hline KB & & - & SR & $\mathrm{R}$ & $\mathrm{R}$ \\
\hline K-AI & & - & - & - & - \\
\hline DHL & & $\mathrm{mmhos} / \mathrm{cm}$ & SR & $\mathrm{S}$ & $\mathrm{S}$ \\
\hline $\mathrm{pH}-\mathrm{H}_{2} \mathrm{O}$ & & - & $\mathrm{am}$ & $\mathrm{Am}$ & $\mathrm{am}$ \\
\hline
\end{tabular}

Keterangan: S (sedang), T (tinggi), R (rendah), SR (sangat rendah), ST (sangat tinggi), am (agak masam)

Tabel 6. Status Kesuburan Tanah (SKT)

\begin{tabular}{ccccccc}
\hline Lokasi & \multicolumn{7}{c}{ Parameter Kesuburan Tanah } & \multirow{2}{*}{ SKT } \\
\cline { 2 - 6 } Sampling & KTK & KB & $\mathbf{P}_{\mathbf{2}} \mathbf{O}_{2}$ & $\mathbf{K}_{\mathbf{2}} \mathbf{O}$ & C-Org & \\
\hline 1 & $\mathrm{R}$ & $\mathrm{SR}$ & $\mathrm{ST}$ & $\mathrm{ST}$ & ST & $\mathrm{R}$ \\
\hline 2 & $\mathrm{R}$ & $\mathrm{R}$ & $\mathrm{ST}$ & $\mathrm{ST}$ & ST & $\mathrm{R}$ \\
\hline 3 & $\mathrm{R}$ & $\mathrm{R}$ & $\mathrm{ST}$ & $\mathrm{ST}$ & ST & $\mathrm{R}$ \\
\hline
\end{tabular}

Keterangan: S (sedang), T (tinggi), R (rendah), SR (sangat rendah), ST (sangat tinggi)

Hasil analisis menunjukan semua sampel (contoh tanah) tingkat kesuburan tanah tergolong Rendah (R). Sedangkan nilai $\mathrm{pH}$ agak masam. Penjelasan mengenai parameter kesuburan tanah ditinjau secara kimia yang dianalisis di laboratorium.

\section{Kualitas Air Tanah}

Analisis kualitas air bersih dari sumber air di lokasi studi diambil dari 2 lokasi dan disajikan pada Tabel 7 dengan membandingkan baku mutu sesuai PERMENKES RI No. 492 Tahun 2010. 
Tabel 7. Hasil Analisis Kualitas Air Tanah

\begin{tabular}{|c|c|c|c|c|c|}
\hline No. & Parameter & Satuan & Titik 1 & Titik 2 & Baku Mutu \\
\hline \multicolumn{6}{|c|}{ Parameter Fisika } \\
\hline 1. & TDS & $\mathrm{mg} / \mathrm{l}$ & 430,65 & 395,55 & 1000 \\
\hline 2. & Kekeruhan & NTU & 12,10 & 20,254 & 5 \\
\hline 3. & Warna & $\mu \mathrm{PtCo}$ & 2,00 & 5,79 & 15 \\
\hline \multicolumn{6}{|c|}{ Parameter Kimia } \\
\hline 1. & $\mathrm{pH}$ & - & 7,01 & 6,41 & $6,5-8,5$ \\
\hline 2. & Fe (besi) & $\mathrm{mg} / \mathrm{l}$ & 2,81 & 2,84 & 0,3 \\
\hline 3. & F (Fluorida) & $\mathrm{mg} / \mathrm{l}$ & $\mathrm{tt}$ & $\mathrm{tt}$ & 1,5 \\
\hline 4. & Cd (Kadmium) & $\mathrm{mg} / \mathrm{l}$ & $\mathrm{tt}$ & $\mathrm{tt}$ & 0,005 \\
\hline 5. & Kesadaan & $\mathrm{mg} / \mathrm{l}$ & 120,52 & 185,65 & 500 \\
\hline 6. & Klorida & $\mathrm{mg} / 1$ & 46,86 & 78,95 & 250 \\
\hline 7. & Krom Total & $\mathrm{mg} / \mathrm{l}$ & $\mathrm{tt}$ & $\mathrm{tt}$ & 0,05 \\
\hline 8. & Mangan, Mn & $\mathrm{mg} / \mathrm{l}$ & 0,86 & 0,256 & 01 \\
\hline 9. & Nitrat $\left(\mathrm{NO}_{3}-\mathrm{N}\right)$ & $\mathrm{mg} / \mathrm{l}$ & 0,019 & 0,025 & 10 \\
\hline 10. & Nitrit $\left(\mathrm{NO}_{2}-\mathrm{N}\right)$ & $\mathrm{mg} / \mathrm{l}$ & $\mathrm{tt}$ & $\mathrm{tt}$ & 1,0 \\
\hline 11. & Seng $(\mathrm{Zn})$ & $\mathrm{mg} / \mathrm{l}$ & 0,23 & 0,27 & 5,0 \\
\hline 12. & Sulfat $\left(\mathrm{SO}_{4}\right)$ & $\mathrm{mg} / \mathrm{l}$ & 74,56 & 95,75 & 400 \\
\hline 13. & Timbal $(\mathrm{Pb})$ & $\mathrm{mg} / \mathrm{l}$ & $\mathrm{tt}$ & $\mathrm{tt}$ & 0,05 \\
\hline 14. & Tembaga $(\mathrm{Cu})$ & $\mathrm{mg} / \mathrm{l}$ & 0,05 & 0,04 & 1,0 \\
\hline 15. & Zat Organik $\left(\mathrm{KMNO}_{4}\right)$ & $\mathrm{mg} / \mathrm{l}$ & 13,14 & 15,70 & 10 \\
\hline 16. & Detergen & $\mathrm{mg} / \mathrm{l}$ & $\mathrm{tt}$ & $\mathrm{tt}$ & 0,05 \\
\hline
\end{tabular}

Keterangan: Titik 1 = Sumur penduduk di Desa Linggar Rancaekek dan Titik 2 = Sumur penduduk di Desa Jelegong Kampung Ciherang

Berdasarkan hasil perbandingan dengan baku mutu Peraturan Pemerintah Republik Indonesia Nomor 492 Tahun 2010 tentang Persyaratan Air Minum, di titik 1 yang berlokasi di Desa Linggar Kecamatan Rancaekek, parameter yang tidak memenuhi baku mutu yaitu kekeruhan, Fe, Mn, dan Zat Organik $\left(\mathrm{KMnO}_{4}\right)$. Sedangkan titik 2 yang berada di Desa Jelegong Kampung Ciherang, parameter yang tidak memenuhi baku mutu yaitu Kekeruhan, $\mathrm{pH}, \mathrm{Fe}, \mathrm{Mn}$, dan zat organik $\left(\mathrm{KMnO}_{4}\right)$. Kualitas air sumur di kedua lokasi titik pemantauan tidak layak untuk di konsumsi harus dilakukan pengolahan terlebih dahulu sebelum dipergunakan untuk kebutuhan sehari-hari. Pengelolaan air yang diperlukan untuk menyisihkan parameter kekeruhan, Fe, Mn dan zat organik $\left(\mathrm{KMnO}_{4}\right)$, bisa menggunakan filter karbon aktif atau proses saringan pasir cepat dengan media karbon aktif.

Beberapa faktor-faktor kekeruhan air ditentukan oleh benda-benda halus yang disuspensikan (seperti lumpur dsb), jasad-jasad renik yang merupakan plankton dan warna air (yang antara lain ditimbulkan oleh zat-zat koloid berasal dari daun-daun tumbuhan yang terekstrak). Faktor-faktor ini dapat menimbulkan warna dalam air. Pengukuran kekeruhan suatu perairan dapat dilakukan dengan menggunakan alat yang disebut dengan Jackson Candler Turbidimeter dengan satuan unit turbiditas setara dengan $1 \mathrm{mg} / 1 \mathrm{SiO}_{2}$. Satu unit turbiditas Jackson Candler Turbidimeter dinyatakan dengan satuan 1 JTU (Jackson Turbidity Unit). Sumber Fe dan Mn berasal dari peluruhan batuan penyusun akuifer yang mengandung $\mathrm{Fe}$ dan $\mathrm{Mn}$ yang tinggi sedangkan tingginya Zat Organik $\left(\mathrm{KMnO}_{4}\right)$ dalam air tanah diprediksi berasal dari rembesan air limbah domestik dan tangki septik atau cubluk yang di buat tidak sesuai kriteria yang ditetapkan yaitu berjarak $10 \mathrm{~m}$ antara sumber air tanah dan tangki septik. Sumber air tersebut kurang layak untuk dikonsumsi sebagai air baku untuk air minum. Tingginya parameter $\mathrm{Fe}, \mathrm{Mn}$, organik, kekeruhan pada sumber air tanah dangkal perlu pengolahan terlebih dahulu sebelum digunakan sebagai air baku untuk air minum karena dikhawatirkan kalau dikonsumsi tanpa pengolahan terlebih dahulu dapat menyebabkan terganggunya kesehatan pengguna air tersebut. 


\subsection{Pengaruh Terhadap Kesehatan Masyarakat}

Sungai Cikijing yang sudah tercemar berdampak terhadap lingkungan sekitarnya. Dampak dari pencemaran Sungai Cikijing dikhawatirkan dapat menurunkan kesehatan masyarakat. Pada bagian ini akan menjabarkan mengenai 10 jumlah penyakit terbanyak yang diderita oleh masyarakat yang tinggal di Sub DAS Cikijing. Data diperoleh dari tiga puskesmas yaitu Puskesmas Cisempur, Sawah Dadap, dan Rancaekek. Gambar 1 menyajikan jumlah 10 penyakit terbanyak rawat jalan di Puskesmas Sawah Dadap berdasarkan semua golongan umur tahun 2015 dan 2016.

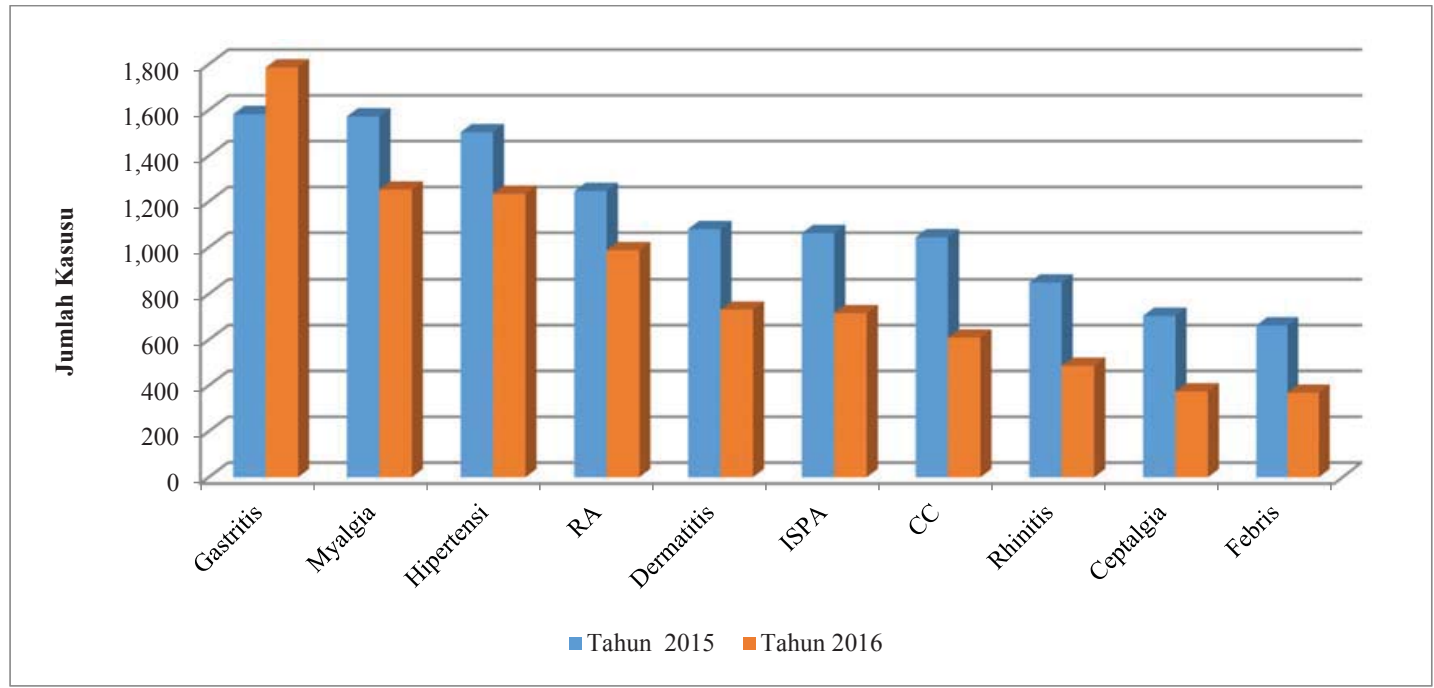

Gambar 1. Jumlah 10 Penyakit di Puskesmas Sawah Dadap

Berdasarkan data yang disajikan pada Gambar 1pada tahun 2015 dan tahun 2016 jumlah penderita paling banyak yang berobat ke Puskesmas Sawah Dadap adalah penyakit Gastristis, kemudian diikuti oleh penyakit Myalgia dan penyakit Hipertensi. Namun pada kedua tahun tersebut terjadi penurunan di 10 jenis penyakit pada tahun 2016, terlihat pada jumlah totalnya tahun 2015 sebanyak 11.305 kasus dan ada tahun 2016 sebanyak 8.543 kasus.

Sedangkan data yang disajikan pada Gambar 2 pada tahun 2015 dan tahun 2016 jumlah penderita paling banyak yang berobat ke Puskesmas Cisempur adalah penyakit ISPA, kemudian diikuti oleh penyakit Gastroenteritis tidak spesifik dan penyakit Myalgia. Namun pada kedua tahun tersebut terjadi peningkatan di 10 jenis penyakit pada tahun 2016, terlihat pada jumlah totalnya tahun 2015 sebanyak 17.442 kasus dan pada tahun 2016 sebanyak 26.544 kasus. 


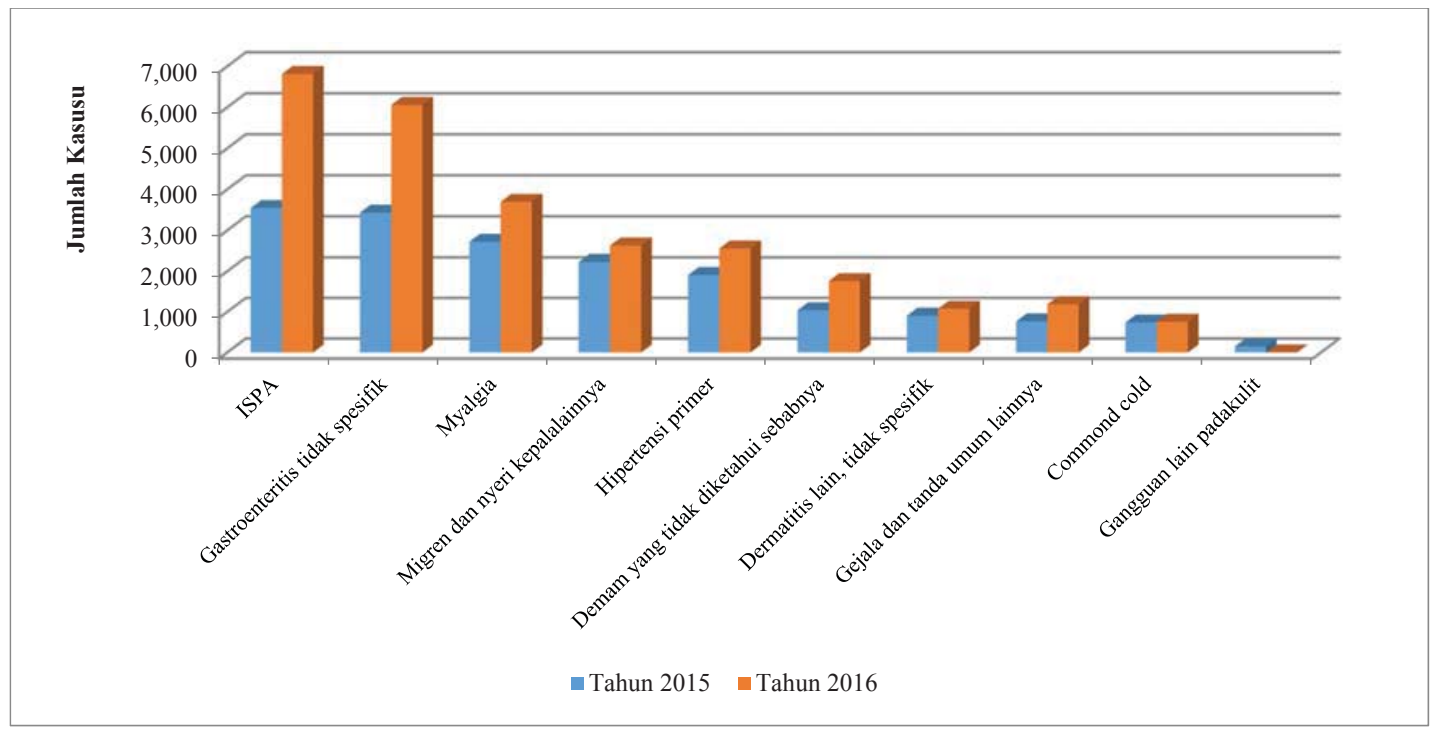

Gambar 2. Jumlah 10 Penyakit di Puskesmas Cisempur

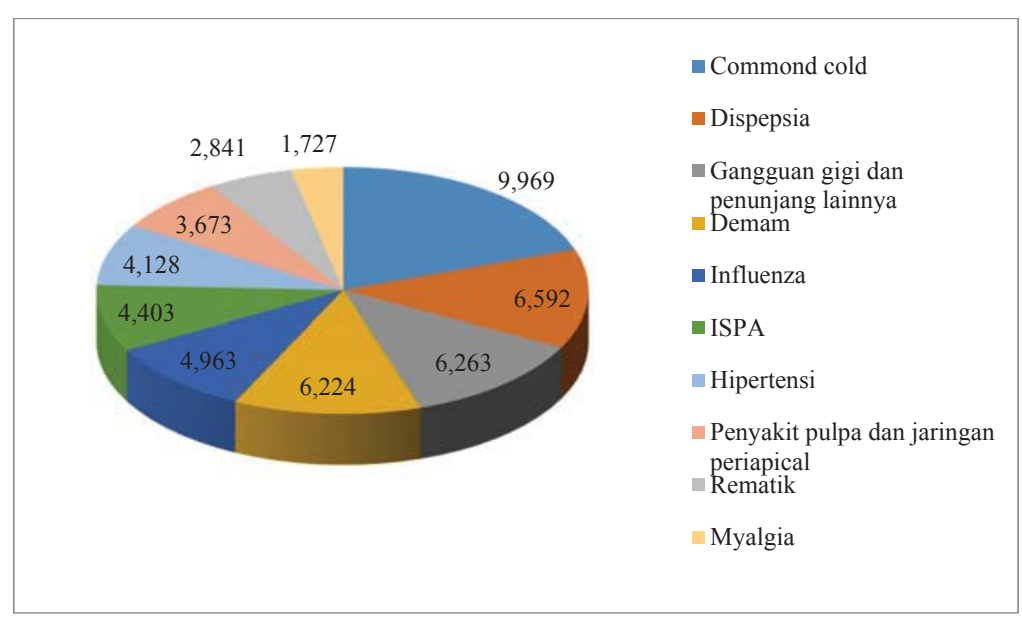

Gambar 3. Jumlah 10 Penyakit di Puskesmas Rancaekek

\section{KESIMPULAN}

Limbah cair yang dihasilkan PT. X terdiri dari limbah industri dan domestik. Limbah industri di proses pada unit IPAL sebelum dialirkan ke Sungai Cikijing. Limbah cair domestik diolah dengan menggunakan tangki septik dan dialirkan langsung ke badan air yang sama. Berdasarkan hasil analisis kualitas air limbah yang telah diolah di IPAL PT X telah memenuhi bakumutu untuk Bulan JanuariJuni 2017. Sampai saat ini IPAL PT X terus meningkatkan efisiensi pengolahan air limbah di IPAL sehingga kualitas air limbah yang dihasilkan berada di bawah bakumutu yang ditentukan. Selain itu juga dilakukan recycle air limbah sebesar 20\% sebagai upaya penghematan penggunaan air tanah serta mengurangi pembuangan air limbah ke Sungai Cikijing. Berdasarkan penelitian sangat sulit melihat dampak langsung pembuangan limbah PT. X terhadap sungai Cikijing mengingat banyaknya sumber pencemar di sungai tersebut. Kualitas air Sungai Cikijing pada Bulan Januari dan Agustus 2017, terdapat beberapa parameter yang tidak memenuhi bakumutu berdasarkan PP 82 Tahun 2001 tentang PKA dan PPA antara lain TSS, TDS, BOD, COD, Detergen MBAS, Belerang $\left(\mathrm{H}_{2} \mathrm{~S}\right)$, Minyak dan Lemak, Nitrit, nitrat dan Fenol. Sumber pencemar yang menyebabkan kualitas air sungai Cikijing diperkirakan berasar dari sektor industri, domestik, pertanian, dan peternakan yang berada di Sub DAS Cikijing. 
Ketidaksuburan tanah di di Kampung Baturumpil Desa Cisempur Kecamatan Jatinangor Kabupaten Sumedang, Kampung Rancakendal Desa Jelegong Kecamatan Rancaekek Kabupaten Bandung, dan Kampung Babakan Jawa Desa Bojongloa Kecamatan Rancaekek Kabupaten Bandung disebabkan oleh alih fungsi lahan dari hutan menjadi tanaman semusim, penggunaan pupuk kimia yang berlebihan, terjadinya erosi sehingga mengikis tanah pucuk. Pencemaran yang terjadi di Sungai Cikijing tidak berpengaruh terhadap penurunan kesuburan tanah, karena air Sungai Cikijing tidak dijadikan sumber air irigasi untuk lahan pertanian di lokasi sampling. Analisis kualitas air bersih di lokasi studi diambil dari 2 lokasi dengan membandingkan bakumutu sesuai PERMENKES RI No. 492 Tahun 2010. Berdasarkan hasil pemeriksaan sumur yang berada di Desa Linggar Kecamatan Rancaekek, parameter yang tidak memenuhi bakumutu yaitu kekeruhan, Fe, Mn, dan zat organik $\left(\mathrm{KmnO}_{4}\right)$. Sedangkan yang berada di Desa Jelegong Kampung Ciherang, parameter yang tidak memenuhi bakumutu yaitu kekeruhan, $\mathrm{pH}, \mathrm{Fe}, \mathrm{Mn}$, dan zat organik $\left(\mathrm{KmnO}_{4}\right)$. Kualitas air sumur di kedua lokasi titik pemantauan tidak layak untuk di konsumsi harus dilakukan pengolahan terlebih dahulu sebelum dipergunakan untuk kebutuhan sehari-hari. Sungai Cikijing yang sudah tercemar dikhawatirkan dapat menurunkan kesehatan masyarakat. Data kesehatan masyarakat diperoleh dari tiga puskesmas yaitu Puskesmas Cisempur, Sawah Dadap, dan Rancaekek tahun 2015 dan 2016 menunjukkan bahwa tidak terdapat kaitan bahwa penyakit yang banyak diserita oleh masyarakat akibat dari pencemaran air sungai Cikijing.

\section{DAFTAR PUSTAKA}

[1] Kecamatan Jatinangor Dalam Angka, 2016 Badan Pusat Statistik Kabupaten Sumedang., 2016

[2] Kecamatan Rancaekek Dalam Angka, 2016 Badan Pusat Statistik Kabupaten Bandung., 2016

[3] Kecamatan Cimanggung Dalam Angka, 2016 Badan Pusat Statistik Kabupaten Sumedang., 2016

[4] Kabupaten Sumedang Dalam Angka, 2016 Badan Pusat Statistik Kabupaten Sumedang., 2016

[5] Kabupaten Bandung Dalam Angka, 2016 Badan Pusat Statistik Kabupaten Bandung., 2016

[6] Lee, T.D. 1978. Handbook of Variables of Environmental Impact assessment. Arbor: An Arbor Science Publisher Inc.

[7] Odum, E.P. (1975). Dasar-dasar Ekologi. Edisi ketiga. Yogyakarta: Gajah Mada. University, press

[8] Peraturan Pemerintah Nomor 82 Tahun 2001. Pengelolaan Kualitas Air dan Pengendalian Pencemaran Air

[9] Peraturan Menteri Kesehatan Republik Indonesia No 492 tahun 2010 tentang Syarat-Syarat dan Pengawasan Air Minum

[10] Profil Puskesmas Cisempur dan Sawah Dadap Dinas Kesehatan Kabupaten Sumedang., 2015

[11] Profil Puskesmas Cisempur dan Sawah Dadap Dinas Kesehatan Kabupaten Sumedang., 2016

[12] Profil Puskesmas Rancaekek Dinas Kesehatan Kabupaten Bandung., 2016 